\title{
Chromosome Numbers in 11 Species of Taraxacum Section ERythrosperma Dt. From Poland
}

\author{
Mateusz Marian Wolanin $^{1 *}$ AND Krystyna Musiat $^{2}$ \\ ${ }^{1}$ Department of Botany, Rzeszów University, Zelwerowicza A. 4, \\ 35-601 Rzeszów, Poland \\ ${ }^{2}$ Department of Plant Cytology and Embryology, Jagiellonian University, \\ Gronostajowa 9, 30-387 Cracow, Poland
}

Received April 3, 2017; revision accepted June 28, 2017

\begin{abstract}
Karyology of eleven species of Taraxacum sect. Erythrosperma from Poland has been studied. Somatic chromosome numbers are given for the following species: T. bellicum, T. brachyglossum, T. cristatum, T. disseminatum, T. dissimile, T. lacistophyllum, T. parnassicum, T. plumbeum, T. proximum, T. scanicum, and T. tenuilobum. Although the hypertriploid chromosome number was previously reported in Poland for T. lacistophyllum, T. parnassicum, T. scanicum, and T. tenuilobum, we proved the triploid chromosome number $2 \mathrm{n}=24$ in all the species investigated, which is consistent with the data reported from other regions of Europe. The chromosome numbers of $T$. bellicum, T. cristatum, T. disseminatum, T. dissimile, T. plumbeum, and T. proximum growing in Poland are published for the first time.
\end{abstract}

Keywords: Asteraceae, Taraxacum, section Erythrosperma, chromosome number, Poland

\section{INTRODUCTION}

Taraxacum Wigg. (Asteraceae-Cichorioideae) is a large genus that contains over 2800 species grouped into 60 sections (Kirschner et al., 2015). Dandelion species form a polyploid complex, with the basic chromosome number $\mathrm{x}=8$, in which the mode of reproduction is closely related to the ploidy level, i.e., diploid dandelions reproduce sexually, while most of the polyploid taxa are apomicts (Richards, 1973). This agamic complex has a wellestablished geographic parthenogenesis in which apomictic taxa have broader and higher-latitude distribution than sexuals (Richards, 1973; Van Dijk, 2003). The majority of Taraxacum species are triploids (more than 50\%), tetraploids are less common (about 30\%) and diploids are quite rare (about 13\%), whereas taxa with higher ploidy levels represent a marginal percentage (den Nijs, 1997).

There are about 380 Taraxacum species in Poland but the chromosome numbers have been recorded only for roughly $10 \%$ of them (Marciniuk et al., 2010; Gacek et al., 2011). Thus, it must be stated that the Polish flora of dandelions is relatively poorly recognized, although cyto- taxonomic studies within the Taraxacum genus were initiated by Prof. Janina Małecka at the turn of the 1970s. She reported the number of chromosomes for more than a dozen of Taraxacum species in Poland belonging to the Palustria and Erythrosperma sections (Małecka, 1967, 1969, 1972, 1973, 1978). Karyological investigations were continued and the chromosome records for ca. 30 Taraxacum species, representing mainly the Palustria and Ruderalia sections, were published in later years (Grzesiuk et al., 2008; Marciniuk et al., 2010; Marciniuk et al., 2012; Kula et al., 2013).

In 2012, the first author undertook taxonomic and chorological research of the Taraxacum sect. Erythrosperma in Poland. After analyzing the available karyological data, it turned out that the chromosome numbers given by Prof. Janina Małecka $(1967,1969)$ for several species belonging to this section differ from the data reported outside Poland. An additional issue was lack of Małecka's herbarium material that could be used to verify the taxonomic identification of the species.

Thus, in order to verify previous reports and to find the missing data, we examined the chromosome numbers of 11 Taraxacum species

\footnotetext{
*Corresponding author, email: wolaninm@wp.pl
} 
representing the Erythrosperma section in Poland. The analyzed species and location of their populations are listed in Table 1.

Plant specimens and mature seeds of the investigated species were collected in natural habitats in the period 2012-2016, from mid-April to mid-May in each of the growing seasons. The plant specimens were used as herbarium material and for cultivation on an experimental field. Specimens of the analyzed taxa were identified by the first author, and their taxonomic identification was additionally confirmed by Dr. Radim Vašut (Palacký University Olomouc, the Czech Republic). The herbarium material is deposited in the herbarium of the Department of Botany, Rzeszów University.

TABLE 1. Taraxacum species examined, along with the locality and geographic coordinates of their populations.

\begin{tabular}{lll}
\hline \hline \multicolumn{1}{c}{ Species } & \multicolumn{1}{c}{ Locality } & \multicolumn{1}{c}{$\begin{array}{c}\text { Geographical } \\
\text { coordinates }\end{array}$} \\
\hline T. bellicum & Kraków & $50^{\circ} 02^{\prime} \mathrm{N} 19^{\circ} 51^{\prime} \mathrm{E}$ \\
T. brachyglossum & Ruda Śląska & $50^{\circ} 15^{\prime} \mathrm{N} 18^{\circ} 50^{\prime} \mathrm{E}$ \\
T. cristatum & Grząby Bolmińskie & $50^{\circ} 48^{\prime} \mathrm{N} 20^{\circ} 21^{\prime} \mathrm{E}$ \\
T. disseminatum & Piątnica near Łomża & $53^{\circ} 11^{\prime} \mathrm{N} 22^{\circ} 06^{\prime} \mathrm{E}$ \\
T. dissimile & Hel & $54^{\circ} 36^{\prime} \mathrm{N} 18^{\circ} 49^{\prime} \mathrm{E}$ \\
T. lacistophyllum & Gdańsk & $54^{\circ} 22^{\prime} \mathrm{N} 18^{\circ} 43^{\prime} \mathrm{E}$ \\
T. parnassicum & Kusięta & $50^{\circ} 46^{\prime} \mathrm{N} 19^{\circ} 16^{\prime} \mathrm{E}$ \\
T. plumbeum & Drezdenko & $52^{\circ} 50^{\prime} \mathrm{N} 15^{\circ} 49^{\prime} \mathrm{E}$ \\
T. proximum & Krynica Morska & $54^{\circ} 23^{\prime} \mathrm{N} 19^{\circ} 28^{\prime} \mathrm{E}$ \\
T. scanicum & Gdańsk & $54^{\circ} 22^{\prime} \mathrm{N} 18^{\circ} 43^{\prime} \mathrm{E}$ \\
T. tenuilobum & Podlesice near Kroczyce & $50^{\circ} 34^{\prime} \mathrm{N} 19^{\circ} 31^{\prime} \mathrm{E}$ \\
\hline
\end{tabular}

For karyological investigations, seeds were germinated on moistened filter paper in Petri dishes. The analysis was carried out on the root tip meristems of young seedlings that were pre-treated with saturated aqueous solution of 8-hydroxychinoline for $4 \mathrm{~h}$ at room temperature and then fixed in a freshly prepared mixture of absolute ethanol and acetic acid $(3: 1, \mathrm{v} / \mathrm{v})$ for $24 \mathrm{~h}$. After fixation, the material was stained in $2 \%$ acetic orcein for 4-5 days at room temperature. Stained seedlings were transferred to $45 \%$ acetic acid and heated to boiling. For slide preparation, root meristems were cut off under a stereoscopic microscope and squashed between a glass slide and coverslip in a drop of $45 \%$ acetic acid. The coverslip was removed after freezing in liquid nitrogen and the slide was air-dried and mounted in Entellan. The chromosome number was established in wellspaced metaphase plates that were photographed using a Nikon Eclipse E400 microscope equipped with a CCD camera.

\section{RESULTS AND DISCUSSION}

Taraxacum bellicum Sonck [synonym: T. prunicolor Mart. Schmid, R. J. Vašut \& P. Oosterveld]; $2 n=24$ (Fig. 1a).

It occurs mainly in Central Europe and has been reported from Austria, the Czech Republic, Slovakia, Germany, Switzerland, and Poland (Euro+Med 2006-; Marciniuk et al., 2009). This species is also known in Finland where it is classified as doubtfully native (Euro+Med 2006-). In Poland we found its several localities in the western part of Lesser Poland (Małopolska), Greater Poland (Wielkopolska) and Podlachia (Podlasie).

This is the first chromosome number report from Poland for this taxon. The triploid chromosome number was earlier given for plants from Germany and the Czech Republic (Table 2).

Taraxacum brachyglossum (Dahlst.) Raunk.; $2 \mathrm{n}=24$ (Fig. $1 \mathrm{~b}$ )

A species best known in North-Western and Western Europe. It has been reported from Ireland, Great Britain, France, Belgium, the Netherlands, Switzerland, Italy, Denmark, Germany, Austria, Italy, Croatia, Norway, Sweden, Finland, Estonia, Poland, Ukraine, Moldova, and Romania (Euro+Med 2006-). It is a naturalized alien species in the USA (Van Soest, 1958). In Poland this taxon has scattered localities in most regions.

The triploid chromosome number matches a previous result obtained for this species in Poland by Małecka (1969). It is also in accordance with the data from Germany for this taxon (Table 2).

Taraxacum cristatum Kirschner, Štěpánek et Vašut; $2 \mathrm{n}=24$ (Fig. 1c)

A species known from the southern part of Central Europe. It has been reported from the Czech Republic, Slovakia, Austria, Hungary, and Poland (Euro+Med 2006-). In Poland it is a rare species. We found only three localities of this species in the north-western part of Lesser Poland (Małopolska).

This is the first chromosome number report from Poland for this taxon. The same chromosome number was given for specimens from the Czech Republic (Table 2).

Taraxacum disseminatum G. E. Haglund; $2 n=24$ (Fig. 1d)

A species known from the western part of Central Europe and the southern part of Northern Europe. It has been reported from France, the Netherlands, Switzerland, Denmark, Germany, Austria, the Czech Republic, Hungary, Norway, 


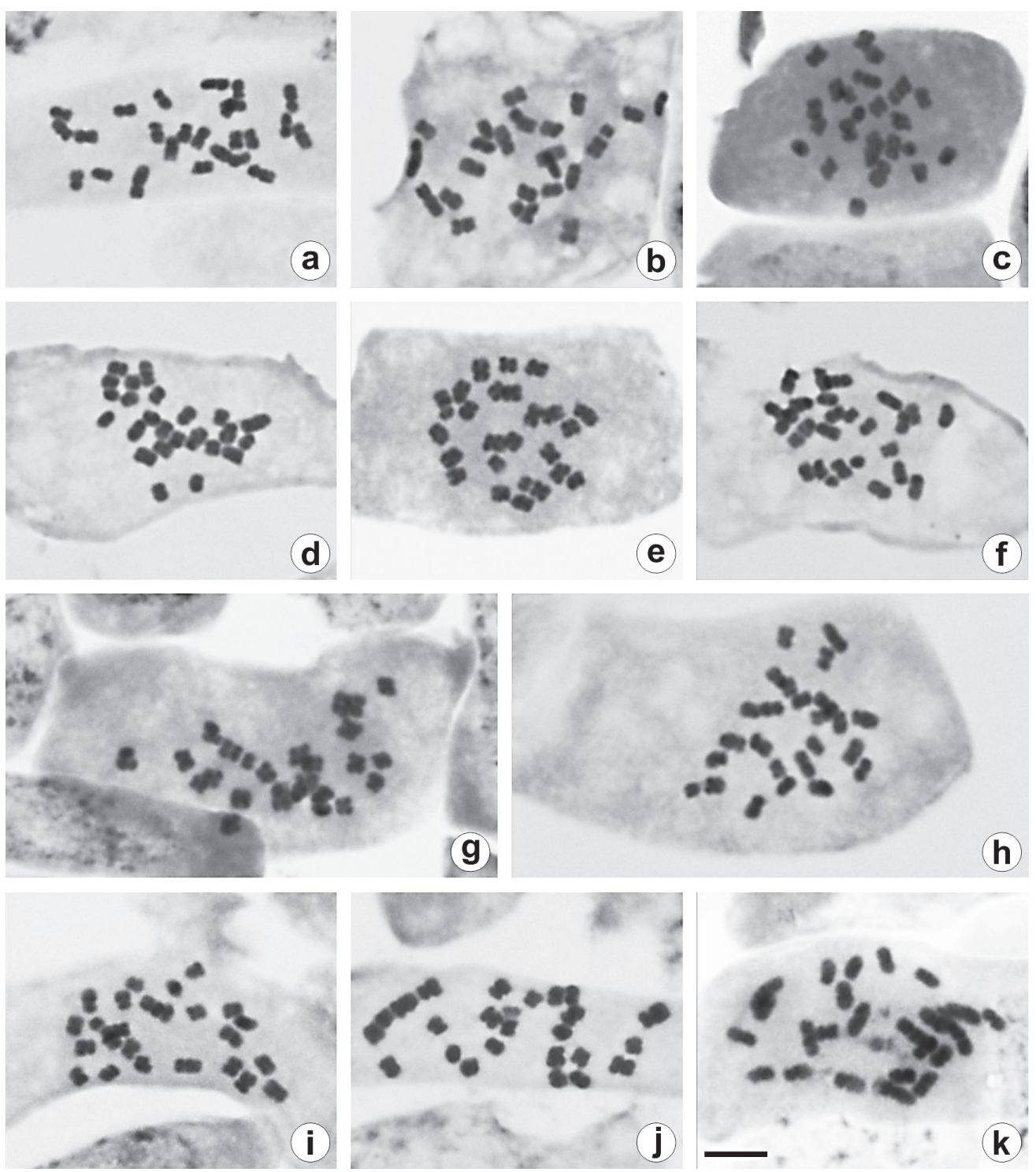

Fig. 1. Mitotic chromosomes of (a) Taraxacum bellicum $2 \mathrm{n}=24$, (b) $T$. brachyglossum $2 \mathrm{n}=24$, (c) $\mathrm{T}$. cristatum $2 \mathrm{n}=24$, (d) $T$. disseminatum $2 \mathrm{n}=24$, (e) $T$. dissimile $2 \mathrm{n}=24$, (f) $T$. lacistophyllum $2 \mathrm{n}=24$, (g) $T$. parnassicum $2 \mathrm{n}=24$, (h) $T$. plumbeum $2 \mathrm{n}=24$, (i) $T$. proximum $2 \mathrm{n}=24$, (j) T. scanicum $2 \mathrm{n}=24$, (k) T. tenuilobum $2 \mathrm{n}=24 ;$ Scale bar in $\mathrm{k}=5 \mu \mathrm{m}$ and corresponds to all figures.

Sweden, Finland, and Poland. This species is also known in Great Britain where it is probably nonnative (Euro+Med 2006-). It is a naturalized alien species in the USA and Canada (Van Soest, 1958). In Poland this taxon is quite rare but we found its scattered localities in Silesia (Ślask), Greater Poland (Wielkopolska), Pomerania (Pomorze) and Podlachia (Podlasie).

This is the first chromosome number report from Poland for this species. The triploid chromosome number agrees with the number reported for plants from Germany and Great Britain (Table 2).
Taraxacum dissimile Dahlst.; 2n = 24 (Fig. 1e)

It occurs mainly in North-Western Europe. It has been reported from Germany, Belgium, the Netherlands, Denmark, Norway, Sweden, Finland, Poland, Estonia, Latvia, Lithuania, Belarus, Ukraine, Central and Northwest European Russia (Euro+Med 2006-). In Poland this species is rare. We found several localities of this species in Podlachia (Podlasie) and Pomerania (Pomorze).

This is the first chromosome number report from Poland for this species. The same chromosome number was given for plants from Scandinavia (Table 2). 
TABLE 2. Chromosome numbers of the examined Taraxacum species - comparison of data from Poland and other parts of Europe.

\begin{tabular}{|c|c|c|c|c|}
\hline Species & Origin & $\begin{array}{c}\text { Somatic } \\
\text { chromosome } \\
\text { number }(2 n)\end{array}$ & Ploidy & Author \\
\hline \multirow[t]{2}{*}{ T. bellicum } & Poland (Kraków) & 24 & $3 \mathrm{x}$ & Wolanin and Musiał \\
\hline & Germany, Czech Republic & 24 & $3 \mathrm{x}$ & Schmid et al., 2004 \\
\hline \multirow[t]{3}{*}{ T. brachyglossum } & Poland (Ruda Śląska) & 24 & $3 x$ & Wolanin and Musiał \\
\hline & Poland & 24 & $3 \mathrm{x}$ & Małecka, 1969 \\
\hline & Germany & 24 & $3 \mathrm{x}$ & Doll, 1973; Uhlemann, 2000 \\
\hline \multirow[t]{2}{*}{ T. cristatum } & Poland (Grząby Bolmińskie) & 24 & $3 \mathrm{x}$ & Wolanin and Musiał \\
\hline & Czech Republic & 24 & $3 \mathrm{x}$ & Vašut et al., 2005 \\
\hline \multirow[t]{3}{*}{ T. disseminatum } & Poland (Piątnica k. Łomży) & 24 & $3 \mathrm{x}$ & Wolanin and Musiał \\
\hline & Germany & 24 & $3 \mathrm{x}$ & Uhlemann, 2000 \\
\hline & British Isles & 24 & $3 \mathrm{x}$ & Dudman and Richards, 1997 \\
\hline \multirow[t]{2}{*}{ T. dissimile } & Poland (Hel) & 24 & $3 \mathrm{x}$ & Wolanin and Musiał \\
\hline & Scandinavia & 24 & $3 \mathrm{x}$ & Gustafsson, 1934 \\
\hline \multirow[t]{4}{*}{ T. lacistophyllum } & Poland (Gdańsk) & 24 & $3 \mathrm{x}$ & Wolanin and Musiał \\
\hline & Poland & 25 & $3 x+1$ & Małecka, 1969 \\
\hline & Germany & 24 & $3 \mathrm{x}$ & Doll, 1973; Uhlemann, 2000 \\
\hline & British Isles & 24 & $3 x$ & Dudman and Richards, 1997 \\
\hline \multirow{5}{*}{ T. parnassicum } & Poland (Kusięta) & 24 & $3 x$ & Wolanin and Musiał \\
\hline & Poland & 26 & $3 x+2$ & Małecka, 1969 \\
\hline & Germany & 24 & $3 \mathrm{x}$ & Doll, 1973; Uhlemann, 2000 \\
\hline & Czech Republic & 24 & $3 \mathrm{x}$ & Kirschner et al., 2011 \\
\hline & British Isles & 24 & $3 x$ & Dudman and Richards, 1997 \\
\hline \multirow[t]{2}{*}{ T. plumbeum } & Poland (Drezdenko) & 24 & $3 x$ & Wolanin and Musiał \\
\hline & Czech Republic & 24 & $3 x$ & Kirschner et al., 2011 \\
\hline \multirow[t]{4}{*}{ T. proximum } & Poland (Krynica Morska) & 24 & $3 \mathrm{x}$ & Wolanin and Musiał \\
\hline & Germany & 24 & $3 \mathrm{x}$ & Doll, 1973; Uhlemann, 2000 \\
\hline & Czech Republic & 24 & $3 \mathrm{x}$ & Kirschner et al., 2011 \\
\hline & British Isles & 24 & $3 \mathrm{x}$ & Dudman and Richards, 1997 \\
\hline \multirow[t]{5}{*}{ T. scanicum } & Poland (Gdańsk) & 24 & $3 \mathrm{x}$ & Wolanin and Musiał \\
\hline & Poland & 25 & $3 x+1$ & Małecka ,1967, 1969 \\
\hline & Poland & 24 & $3 x$ & Grzesiuk et al., 2008 \\
\hline & Germany & 24 & $3 \mathrm{x}$ & Doll, 1973; Uhlemann, 2000 \\
\hline & Czech Republic & 24 & $3 x$ & Kirschner et al., 2011 \\
\hline \multirow[t]{3}{*}{ T. tenuilobum } & Poland (Podlesice k. Kroczyc) & 24 & $3 \mathrm{x}$ & Wolanin and Musiał \\
\hline & Poland & 25 & $3 x+1$ & Małecka, 1969 \\
\hline & Germany & 24 & $3 x$ & Uhlemann, 2000 \\
\hline
\end{tabular}

Taraxacum lacistophyllum (Dahlst.) Raunk.; $2 \mathrm{n}=24$ (Fig. 1f)

This species occurs mainly in North-Western Europe. It has been reported from Ireland, Great Britain, Portugal, Spain, France, Corsica, Italy, Belgium, the Netherlands, Switzerland, Denmark, Germany, the Czech Republic, Hungary, Sweden, Finland, Poland, Latvia, and Lithuania (Euro+Med
2006-). It is a naturalized alien species in the USA and Canada (Van Soest, 1958). In Poland we found numerous localities of this taxon in Pomerania (Pomorze).

Małecka (1969) reported the hypertriploid chromosome number $(2 n=25)$ in Poland for this taxon, however, our present karyological study showed the triploid chromosome number in plants 
from Gdańsk. The triploid chromosome number was also reported for specimens from Germany and the British Isles (Table 2).

Taraxacum parnassicum Dahlst. [synonym: T. silesiacum G. E. Haglund]; 2n = 24 (Fig. 1g)

It is a widespread species in Europe. It has been reported from Ireland, Great Britain, France, Belgium, the Netherlands, Switzerland, Italy, Corsica, Denmark, Germany, Austria, Poland, the Czech Republic, Slovakia, Hungary, Montenegro, Greece, Macedonia, Ukraine, Romania, and Bulgaria (Euro+Med 2006-). It is a naturalized alien species in Sweden and the USA (Van Soest, 1958; Euro+Med 2006-). In Poland this species occurs in Lesser Poland (Małopolska), Silesia (Ślask) and Greater Poland (Wielkopolska). We observed this species quite often in the Kraków-Częstochowa Upland.

The hypertriploid chromosome number $(2 \mathrm{n}=26)$ for this taxon was reported from Poland by Małecka (1969), whereas in the course of the present study the triploid chromosome number $(2 n=24)$ was established in plants from Kusięta. The triploid chromosome number is in accordance with the data from Great Britain, Germany and the Czech Republic (Table 2).

Taraxacum plumbeum Dahlst.; 2n $=24$ (Fig. 1h)

It occurs mainly in Central Europe and has been reported from Germany, Switzerland, Austria, Italy, Poland, the Czech Republic, Slovakia, and Sweden (Euro+Med 2006-). In Poland this species is not common but its scattered localities are recorded in most regions of the country.

This is the first chromosome number report from Poland for this species. The same chromosome number was given for plants from the Czech Republic (Table 2).

Taraxacum proximum (Dahlst.) Raunk.; 2n $=24$ (Fig. 1i)

A species known mainly in Northern and Western Europe. It has been reported from Great Britain, Iceland, France, Belgium, the Netherlands, Switzerland, Denmark, Germany, Austria, the Czech Republic, Slovakia, Norway, Sweden, Poland, Hungary, Finland, Estonia, Latvia, Lithuania, Moldova, Bulgaria, Ukraine, Central and Northern to Eastern Russia (Euro+Med 2006-). It is a naturalized alien species in the USA (Van Soest, 1958). In Poland it occurs quite frequently in Greater Poland (Wielkopolska) but we recorded this species also in Lower Silesia (Dolny Ślask) and Pomerania (Pomorze).

This is the first chromosome number report from Poland for this species. The triploid chromosome number was earlier given for plants from the British Isles, Germany and the Czech Republic (Table 2).
Taraxacum scanicum Dahlst.; $2 \mathrm{n}=24$ (Fig. 1j)

This species occurs mainly in North-Western and Western Europe and has been reported from Great Britain, France, Belgium, the Netherlands, Switzerland, Italy, Denmark, Germany, Austria, Croatia, the Czech Republic, Norway, Sweden, Poland, Hungary, Finland, Estonia, Latvia, Lithuania, Moldova, Ukraine, Central and Northwest European Russia (Euro+Med 2006-). Moreover, it has been naturalized in the USA and Canada (Van Soest, 1958). In Poland we noted the scattered localities of this species mainly in the north of the country.

The hypertriploid chromosome number $(2 n=25)$ was previously found in the specimens of this taxon from Poland (Małecka, 1967, 1969). However, Grzesiuk et al. (2008) reported the triploid chromosome number $(2 \mathrm{n}=24)$ for this species, which is consistent with the data for Western European populations (Table 2). At present, we confirmed the triploid chromosome number in seedlings grown from seeds collected in Pomerania (Pomorze).

Taraxacum tenuilobum (Dahlst.) Dahlst.; $2 \mathrm{n}=24$ (Fig. 2k)

This species occurs in North-Western Europe and western part of Eastern Europe and has been reported from the Netherlands, Germany, Switzerland, Denmark, Poland, Norway, Sweden, Latvia, Estonia, Ukraine, Moldova and Central to Northwest European Russia (Euro+Med 2006-). In Poland we found this species in scattered localities in Lesser Poland (Małopolska), Podlachia (Podlasie) and Pomerania (Pomorze).

Małecka (1969) reported the hypertriploid chromosome number $(2 \mathrm{n}=25)$ for this taxon occurring in Poland but in the present study, we established the triploid chromosome number in the analyzed plants originating from Gdańsk. The triploid chromosome number was also reported for this species in Germany (Table 2).

\section{AUTHORS' CONTRIBUTIONS}

MW - research design, field investigations, material collection, species determination, manuscript writing; KM - karyological analysis, interpretation of results and preparation of figures, manuscript writing. The authors have declared that there is no conflict of interest.

\section{ACKNOWLEDGEMENTS}

We would like to gratefully thank Dr. Radim Vašut (Palacký University Olomouc, the Czech Republic) for his confirmation of the taxonomic identification 
of the dandelion species. This work was supported by statutory research funds of the Department of Botany, Faculty of Biology and Agriculture of Rzeszów University and the Department of Plant Cytology and Embryology of the Institute of Botany, Faculty of Biology and Earth Sciences of the Jagiellonian University in Cracow.

\section{REFERENCES}

DEN NIJS JCM. 1997. Taraxacum: ploidy levels, hybridization and speciation, the advantage and consequence of combining reproductive systems. Lagascalia 19: 45-56.

Doll R. 1973. Revision der sect. Erythrosperma Dahlst. emend. Lindb. f. der Gattung Taraxacum Zinn. 2. Teil. Feddes Repertorium 84: 1-180.

DudMAN AA, and RichARDS AJ. 1997. Dandelions of Great Britain and Ireland. Botanical Society of the British Isles. Handbook No 9, London.

Euro+MEd (2006-): Euro+Med PlantBase - the information resource for Euro-Mediterranean plant diversity. Published on http://ww2.bgbm.org/EuroPlusMed/ [accessed 10.02.2017].

Gacek P, Goralski G, and Joachimiak AJ. 2011. Chromosome numbers and polyploidy in Polish Angiosperms. Acta Biologica Cracoviensia Series Botanica 53(2): 37-49.

Grzesiuk A, MarciniuK J, and Marciniuk P. 2008. Chromosomal diversity among Polish origin species of Taraxacum genus. Electronic Journal of Polish Agricultural Universities, Biology 11(4): \#14.

Gustafsson A. 1934. Die Formenbildung der Totalapomikten. Hereditas 19: 259-283.

Kirschner J, ŠTĚPÁNeK J, TRÁVNíčEK B, and VAŠUt RJ. 2011. Taraxacum Wigger - pampeliška (smetánka). In: Štěpánková J [ed.], Květena České Republiky 8: 23-269, Praha: Academia.

Kirschner J, ZÁvesKá DrÁBKová L, ŠTĚPÁNEK J, and UHLEMANN I. 2015. Towards a better understanding of the Taraxacum evolution (Compositae-Cichorieae) on the basis of nrDNA of sexually reproducing species. Plant Systematics and Evolution 301: 1135-1156.

Kula A, Grabowska-Joachimiak A, Kasjaniuk M, Legutko J, MARCINIUK P, and Musiat K. 2013. Chromosome numbers in 10 Taraxacum species from Poland. Acta Biologica Cracoviensia Series Botanica 55(2): 153-157.
MAŁECKA J. 1967. Cyto-embryological studies in Taraxacum scanicum Dt. Acta Biologica Cracoviensia Series Botanica 10: 195-208.

MAŁECKA J. 1969. Further cyto-taxonomic studies in the genus Taraxacum section Erythrosperma Dt. I. Acta Biologica Cracoviensia Series Botanica 12: 57-72.

MAŁECKA J. 1972. Further cyto-taxonomic studies in the genus Taraxacum section Palustria Dahlstedt. Acta Biologica Cracoviensia Series Botanica 15: 113-126.

MAŁECKA J. 1973. Problems of the mode of reproduction in microspecies of Taraxacum section Palustria Dahlstedt. Acta Biologica Cracoviensia Series Botanica 16: 37-84.

MA£ECKA J. 1978. Further cyto-taxonomic studies in the genus Taraxacum section Palustria Dahlstedt. Part III. Acta Biologica Cracoviensia Series Botanica 21: 109-115.

Marciniuk J, Vašut RJ, Marciniuk P, and CZARna A. 2009. Taraxacum scanicum Dahlst. group (section Erythrosper$\mathrm{ma}$ ) in Poland: chorology and seed and pollen morphology of the microspecies. Acta Societatis Botanicorum Poloniae 78(2): 115-121.

MarciniuK J, ReraK J, Grabowska-Joachimiak A, JastrząB I, Musiat K, and JOACHIMIAK AJ. 2010. Chromosome numbers and stomatal cell length in Taraxacum sect. Palustria from Poland. Acta Biologica Cracoviensia Series Botanica 52(1): 117-121.

Marciniuk P, Musiat K, Joachimiak AJ, MarciniuK J, OKLeJeWICZ K, and Wolanin M. 2012. Taraxacum zajacii (Asteraceae) a new species from Poland. Annales Botanici Fennici 49(5-6): 387-390.

RICHARDS AJ. 1973. The origin of Taraxacum agamospecies. Botanical Journal of the Linnean Society 66: 189-211.

SCHMID M, VAŠUt RJ, and OOSTERVELD P. 2004. Taraxacum prunicolor sp. nova, a new species of the Taraxacum scanicum group (sect. Erythrosperma). Feddes Repetorium 115(3-4): 220-229.

Uhlemann I. 2000. Cytogeographische und karyotaxonomische Untersuchungen in der Gattung Taraxacum Wiggers (Asteraceae). Dissertation, TU Dresden.

VAN DIJK PJ. 2003. Ecological and evolutionary opportunities of apomixis: insights from Taraxacum and Chondrilla. Philosophical Transactions of the Royal Society B: Biological Sciences 358: 1113-1121.

VAn Soest JL. 1958. Taraxacum sectio Erythrosperma Dahlstedt em. Lindberg f. in North-America. Acta Botanica Neerlandica 7: 627-628.

VAŠUt RJ, ŠTĚPÁNEK J, and KIRSCHNER J. 2005. Two new apomictic Taraxacum microspecies of the section Erythrosperma from Central Europe. Preslia 77: 197-210. 